Leadership: Jurnal mahasiswa manajemen Pendidikan Islam

ISSN (P): 2721-7108, ISSN (E): 2715-0399

DOI : http://dx.doi.org/10.32478/leadership. v3i1.874

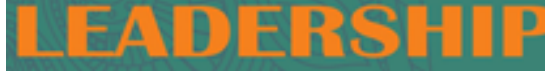

Article Type : Original Research Article

\title{
Strategi Kepala Sekolah Dalam Meningkatkan Mutu Pendidikan (Studi Kasus Madrasah Aliyah Bahrul Ulum Tajinan Kabupaten Malang)
}

\author{
Hasyim Mujadi
}

STAI Ma'had Aly Al-Hikam Malang, Indonesia

Corresponding author: Email: hasyimmujadi@gmail.com

\author{
Submission Track: \\ Submisson : :03-01-2022 \\ Accept Submission : 04-01-2022 \\ Avaliable Online : :04-01-2022
}

Copyright @ 2022 Author

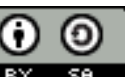

This work is licensed under a Creative Commons Attribution-ShareAlike 4.0

\begin{abstract}
Madrasah Aliyah Bahrul Ulum Tajinan Malang is one of the educational institutions under the auspices of the Bahrul Ulum Tajinan Islamic Boarding School Foundation, Malang. This Madrasah is very thick with its religious atmosphere, because it stands in a pesantren environment. This madrasah has good quality education seen for the several programs it has, namely 8 excellent programs., as well as standart operational for learning noble character and habituation of noble character. In addition, this madrasah also has several prominent programs, they are: 1) discipline, 2) dhuha prayer activities and reading yaaseen, 3) complete facilities and infrastructure. Therefore, the author wants to examine how the principal's strategy in improving the quality of education at Madrasah Aliyah Bahrul Ulum.
\end{abstract}

This research was conducted in Madrasah Aliyah Bahrul Ulum Tajinan Malang. Research data obtained through observation, interviews, and documentation. To check the validity of the data using triangulation of sources and methods. Data analysis uses interaction model analysis techniques with three stages, namely data reduction, data presentation, and drawing conclusion.

The results of the study, the principla's strategy in improving the quality of education in Madrasah Aliyah Bahrul Ulum Tajinan Malang are namely, 1) improving the quality of educators and education, 2) fostering the discipline of 
Leadership: Jurnal mahasiswa manajemen pendidikan Islam

ISSN (P): 2721-7108, ISSN (E): 2715-0399

Vol. 03 No. 01 bulan Desember 2021

teachers and students, 3) increasing the effectiveness of learning, 4) improving madrasah facilities and infrastructure, 5) improving the quality of learning and stucent achievement, 6) evaluation of teaching and learning process, and 7) promoting madrasah.

Keywords: Principal Strategy, Improving Education Quality

\begin{abstract}
Abstrak
Madrasah Aliyah Bahrul Ulum Tajinan Kabupaten Malang adalah salah satu lembaga pendidikan yang berada di bawah naungan Yayasan Pondok Pesantren Bahrul Ulum Tajinan Kabupaten Malang. Madrasah ini sangat kental dengan suasana agamisnya, karena berdiri di lingkungan pesantren. Madrasah ini mempunyai mutu pendidikan yang baik, dilihat dari beberapa program yang dimiliki yaitu 8 program unggulan, pendidikan karakter 3S (Salam, Sapa, dan Salim), serta SOP pembelajaran akhlaq mulia dan pembiasaan akhlaq mulia. Di samping itu Madrasah Aliyah Bahrul Ulum ini juga mempunyai beberapa program yang menonjol, yaitu: 1) kedisiplinan, 2) kegiatan sholat dhuha berjamaah dan pembacaan surat Yasin, 3) sarana dan prasarana yang cukup lengkap. Maka sebab itu penulis mengangkat tema ini untuk dilakukan penelitian yakni tentang bagaimana strategi kepala sekolah dalam meningkatkan mutu pendidikan di Madrasah Aliyah Bahrul Ulum.

Penelitian ini dilaksanakan di Madrasah Aliyah Bahrul Ulum Tajinan Kabupaten Malang. Data penelitian didapatkan dengan cara pengamatan, wawancara, dan dokumentasi. Untuk memastikan mengenai kevalidan data yakni memakai metode pencarian tempat-tempat yang diketahui dan menggunakan pendapat-pendapat orang lain yang membantu, sumber dan metode. Sedangkan dalam menganalisis data, penulis memakai teknik interaksi, yang memerlukan tiga langkah berurutan, yakni reduksi data, penyajian data, dan penarikan kesimpulan.

Penelitian ini menghasilkan bahwa strategi kepala sekolah dalam upayanya untuk mencapai peningkatan mutu pendidikan di Madrasah Aliyah Bahrul Ulum Tajinan Kabupaten Malang yaitu: 1) meningkatkan kualitas tenaga pendidik dan kependidikan, 2) pembinaan kedisipilan guru dan peserta didik, 3) meningkatkan efektifitas pembelajaran, 4) meningkatkan sarana dan prasarana madrasah, 5) meningkatkan kualitas belajar dan prestasi peserta didik, 6) evaluasi proses belajar mengajar,dan 7) mempromosikan madrasah.
\end{abstract}

Kata Kunci: Strategi Kepala Sekolah, Meningkatkan Mutu Pendidikan

A. Pendahuluan

Peran utama pendidikan dalam suatu bangsa adalah meningkatkan kualitas hidup manusia. Karena dengan pendidikan inilah manusia diharuskan untuk menentukan arah, tujuan, dan makna kehidupan. Pendidikan yang bermutu menjadi suatu faktor terpenting dari suatu negara untuk mempersiapkan generasi penerus masa yang akan datang. Sehingga pendidikan wajib diperhatikan secara khusus dari pemerintah dalam perbaikan kualitas manusia.

Selain upaya dan posisi pemerintah untuk turut serta dalam upaya improvisasi terhadap kualitas dan mutu pendidikan, disini kepala sekolah yang juga merupakan 
leader, memiliki posisi yang sentral, besar dan penting. Karena kepala sekolah dapat mempengaruhi berhasil tidaknya kualitas lembaga pendidikan di sekolah itu sendiri. Terwujudnya hasil atau gol dari pendidikan tidak serta merta dapat dirai bergitu saja, melainkan memerlukan kepada skill dan kebijakan kepala sekolah. Ini dikaarenakan bahwa kepala sekolah mempunyai fungsi utama yaitu mengkreasikan situasi dan kondisi belajar dan mengajar yang kondusif, sehingga pendidik/ pengajar dan murid dapat menjalankan aktifitasnya dalam menransfer dan menerima ilmu dengan baik. ${ }^{1}$

Setiap kepala sekolah memiliki strategi kepemimpinan yang berbeda dalam menjalankan kewajiban berupa tugas dan fungsinya. Kepala sekolah merupakan kunci utama dalam menentukan berhasil tidaknya suatu lembaga pendidikan. Karena kepala sekolah merupakan seorang yang memegang kemudi untuk mengarahkan dan mengendalikan jalan yang akan dilalui sekolah untuk sampai kepada tujuannya. Keberhasilan strategi yang diaplikasikan oleh kepala sekolah sangat tergantung pada kemampuan kepemimpinan dalam mendirikan komitmen, mengaitkan taktik dan visi misi yang tepat, mengelola sumber daya yang menyuport implementasi strategi. ${ }^{2}$

Membahas tentang strategi kepala sekolah dalam meningkatkan mutu pendidikan, maka peneliti menjadikan Madrasah Aliyah Bahrul Ulum Tajinan Kabupaten Malang sebagai objek penelitian skripsinya. Madrasah ini termasuk dari salah satu lembaga pendidikan yang berposisi dalam naungan Dinas Pendidikan dan Kementerian Agama Kabupaten Malang. Sekaligus menjadi salah satu lembaga yang ditelorkan oleh Yayasan Pondok Pesantren Bahrul Ulum, yang berada di Jalan Raya Tajinan No. 50 Kecamatan Tajinan Kabupaten Malang.

Dibawah kepemimpinan Bapak Noer Azizi, M.Pd.I Madrasah ini semakin berkembang pesat tahun demi tahun. Hal ini dapat dilihat dari arah prestasi maupun meningkatnya input kuantitas siswa-siswi baru setiap tahunnya. Menurut peneliti sendiri strategi kepala sekolah yang dilakukan oleh Bapak Noer Azizi, M.Pd.I dalam meningkatkan mutu pendidikan salah satu contohnya adalah beliau mampu menjalin hubungan baik dengan kalangan masyarakat luas sehingga banyak mendapat simpati.

Maka sebab itu, peneliti sangat tertarik untuk mengangkat sekolah ini menjadi sebuah penelitian, yang lebih memfokuskan terhadap strategi kepala sekolah dalam upaya peningkatan dan improvisasi mutu pendidikan. Sehingga penelitian ini memiliki tujuan, yaitu: 1) untuk mendapatkan pengetahuan dan mendiskripsikan strategi kepala sekolah dalam upaya peningkatan dan improvisasi mutu pendidikan di Madrasah Aliyah Bahrul Ulum Tajinan Kabupaten Malang. 2) Untuk mendapatkan pengetahuan tentang faktor-faktor yang mendukung kepala sekolah dalam upaya peningkatan dan improvisasi mutu pendidikann di Madrasah Aliyah Bahrul Ulum Tajinan Kabupaten Malang.

\section{B. Metode Penelitian}

1. Jenis Penelitian.

Berdasarkan konteks penelitian yang diangkat dalam penelitian ini yakni tentang Strategi Kepala Sekolah Dalam Meningkatkan Mutu Pendidikan Di Madrasah Aliyah Bahrul Ulum Tajinan Kabupaten Malang, maka penelitian ini berjenis case study atau

${ }^{1}$ Ghaffar MS, Dasar-dasar Administrasi dan Supervisi Pengajaran, (Jakarta: Angkasa Raya, 1992), hlm. 154.

${ }^{2}$ Sofan amari, Peningkatan Mutu Pendidikan sekolah Dasar \& Menengah, (Jakarta: Prestasi Pustaka, 2013), hlm. 18. 
Leadership: Jurnal mahasiswa manajemen pendidikan Islam

ISSN (P): 2721-7108, ISSN (E): 2715-0399

Vol. 03 No. 01 bulan Desember 2021

studi kasus. Penelitian ini menerapkan metode kualitatif (qualitative method). Sedangkan penelitian ini menerapkan pendekatan deskriptif analisis. ${ }^{3}$

2. Instrumen Penelitian

Peneliti sebagai variable inti yang memiliki peran sebagai subjek yang merencanakan penelitian, mengumpulkan data, dan menafsirkan data. ${ }^{4}$ Peneliti berusaha memperoleh data tentang strategi kepala sekolah dalam meningkatkan mutu pendidikan di Madrasah Aliyah Bahrul Ulum Tajinan Kabupaten Malang. Adapun untuk memberikan kemudahan bagi peneliti dalam upaya mengoleksi data, maka peneliti perlu merumuskan wawancara dan observasi yang berkaitan dengan hal tersebut.

3. Subjek Penelitian

Lokasi penelitian ini adalah Madrasah Aliyah Bahrul Ulum yang merupakan suatu institusi pendidikan yang berlokasi di wilayah Malang Selatan tepatnya di Jalan Raya No. 50 Tajinan Kecamatan Tajinan Kabupaten Malang Provinsi Jawa Timur. Sementara itu yang berperan sebagai subjek penelitiannya adalah kepala sekolah, ketua yayasan, waka kurikulum, waka kesiswaan, bendahara, staf TU, security.

4. Teknik Pengumpulan Data

a. Wawancara

Manusia memiliki kedudukan sebagai informan, menjadikan ia sumber data yang urgen dalam suatu penelitian yang menerapkan metode kualitatif. Oleh karena itu, perlu dilakukan wawancara kepada beberapa orang yang dianggap memahami problem yang dikaji. Peneliti menerapkan teknik wawancara terstruktur dan tidak terstruktur.

b. Observasi

Pengamatan dalam penelitian adalah salah satu tahapan dalam pengeumpulan data yang cukup lengkap dan kompleks. Karena harus mengamati sesuatu yang Nampak dari sisi biologis, dan juga yang tidak nampak dari sisi kejiwaan. Sedangkan yang terpenting dari pengematan (observasi) ini adalah penghafalan atau perekaman. $^{5}$

c. Dokumentasi

Dokumentasi ini menjadi salah satu metode dalam teknik mengoleksi data, melalui cara menelaah, mempelajari, melakukan upaya penggalian data, penyelidikan terhadap data dan menyelidiki data yang telah tersimpan dalam bentuk arsip yang telah terdokumentasi terkait dengan peningkatan mutu pendidikan di Madrasah Aliyah Bahrul Ulum Tajinan. ${ }^{6}$

5. Teknik Analisis Data

Untuk menyampaikan arti tentang informasi dan data yang terkumpul dari lapangan, selanjutnya melakukan tahapan menganalisis data. Aktifitas ini secara berkesinambungan sejak dimulainya proses pengumpulan data sampai penelitian ini dinyatakan berkahir. Terdapat suatu cara yang dijalankan dalam mengenalisis data ini adalah melewai tahapan-tahapan sebagai berikut:

a. Reduksi Data

\footnotetext{
${ }^{3}$ Sugiono, Metode Penelitian Kuantitatif, Kualitatif, dan R\&D, (Bandung: Alfabeta, 2006), hlm. 137. ${ }^{4}$ Lexy J. Moleong, Metodologi Penelitian Kualitatif (Bandung: Remaja Rosdakarya, 2010), hlm. 168. ${ }^{5}$ Sugiyono, Metode Penelitian Pendidikan, (Bandung: Alfabeta, 2007), hlm. 203.

${ }^{6}$ Suharsimi Arikunto, Prosedur Penelitian Suatu Pendekatan Praktek, (Jakarta: Rineka Cipta, 2002), hlm. 135.
} 
Kegiatan ini diterapkan melalui cara penyeleksian data dari lapangan yang tersusun di dalam laporan. Caranya adalah dengan melakukan penyusunan ulang kedalam bentuk laporan dan uraian secara rinci. Langkah berikutnya adalah merangkum laporan yang sudah dilakukan perduksian yang kemudian dilakukan penyeleksian dengan menjadikan pokok dan data yang relevan dengan fokus peneltian sebagai dasarnya. ${ }^{7}$

b. Display Data

Display data atau penyajian data adalah upaya melakukan penyusunan data yang dianggap rumit dan komplek menjadi lebih sistematis, dengan tujuan untuk menyederhanakan data sehinggan lebih mudah untuk dipahami. ${ }^{8}$

c. Penarikan Kesimpulan

Sesudah data dicatat di dalam tampilan data, maka peneliti dapat menyimpukan dengan menengok kepada suatu kesamaan dan perbedaan mengenai ungkapan yang dikeluarkan oleh subjek penelitian, hingga memiliki arti. ${ }^{9}$

6. Pengecekan Keabsahan Data

Agar penelitian ini dapat dipertanggungjawabkan, maka perlu dilakukan pengecekan keabsahan data sebagai dasarnya. ${ }^{10}$ Oleh karena itu, peneliti memakai beberapa teknik keabsahan data, meliputi: kredibilitas, transferabilitas, dependabilitas, dan konfirmabilitas. ${ }^{11}$

\section{Landasan Teori}

1. Strategi Kepala Sekolah

a. Pengertian Strategi

Strategi dal bidang pendidikan, sering diberikan pengertian sebagai suatu upaya dalam merencanakan mengenai runtutan aktifitas yang dirancang khusus demi terwujudnya suatu tujuan dari pendidikan. ${ }^{12}$ Seperti pendapat yang dikemukakan oleh Cagne, yang kemudian dikutip oleh Iskandar Wassid dan Dadang Sunendar, bahwa dalam bingkai strategi, mengajar adalah suatu skill atau keterampilan berpikir, menyelesaikan masalah, dan menentukan keputusan. dari dalam diri seseorang.

Mengacu kepada beberapa pandangan di atas, bahwa strategi di sini adalah media yang dipakai untuk mendapatkan keberhasilan demi meraih tujuan yang telah ditentukan. Untuk merealisasikan strategi yang sukses, ada beberapa petunjuk megenai membuat strategi agar bisa berhasil, antara lain: (1) Strategi diharuskan senantiasa menyesuaikan dengan lingkungannya, (2) Strategi tidak cukup hanya mengkreasikan sebuah strategi, (3) Untuk mencapai keefektifan dalam strategi diharuskan konsen dan fokus, serta mepersatukan semua, (4) Strategi harus fokus pada hal yang menjadi kekuatannya dan bukan pada hal-hal yang menjadi kelemahannya. (5) Sumber daya merupakan suatu hal yang sangat

\footnotetext{
${ }^{7}$ S. Nasution, Metode Penelitian Natwalistik-Kualitatif, (Baajaag: Tlasito, 1998), hlm. 96.

${ }^{8}$ Ahmad Sonhaji, Metode Penelitian Kualitatif Dalam Pendidikan, (Banjarmasin: Universitas Lambung Mangkurat, 2003), hlm. 27.

${ }^{9}$ S. Nasution, Metode Penelitian Natwalistik-Kualitatif, (Baajaag: Tlasito, 1998), hlm. 27.

${ }^{10}$ Lexy J, Moleong, Metodologi Penelitian Kualitatif....., hlm. 320.

${ }^{11}$ Rulam Ahmadi, Memahami Metodologi Penelitian, (Bandung: Remaja Rosdakarya, 2010), hlm. 170.

${ }^{12}$ Wina Sanjaya, Strategi Pembelajaran Berorientasi Standar Proses Pendidikan, (Jakarta: Kencana

Prenada Media Grop, 2006), hlm. 126.
} 
penting, (6) Strategi harus dapat mengendalikan risiko yang tidak terlalu besar (7) Strategi harus disusun berdasarkan keberhasilan yang telah dicapai, (8) Strategi yang berhasil ditunjukkan dengan adanya dukungan dari pihak-pihak terkait terutama dari pihak eksekutif, dan seluruh pimpinan unit kerja dalam organisasi. ${ }^{13}$

Menurut Crown dalam Agustinus, membagi strategi dalam tiga tahapan, yaitu: (1) Perumusan strategi yang meliputi penyusunan strategi alternatif, pemilihan strategi, dan penentuan strategi yang digunakan; (2) Penerapan strategi yang menekankan pada beberapa hal, antara lain penetapan tujuan tahunan, penetapan kebijakan, motivasi pegawai, pengembangan budaya yang mendukung, penetapan struktur organisasi yang efektif, penyusunan anggaran, pemanfaatan sistem informasi, dan hubungan antara kompensasi pegawai dengan kinerja organisasi. ; (3) Pengendalian strategis terdiri dari tiga tahap, yaitu mengkaji faktor internal dan eksternal, menilai kinerja strategi, dan mengambil langkah-langkah perbaikan. ${ }^{14}$

b. Pengertian Kepala Sekolah

Dalam organisasi pendidikan, pemimpin pendidikan adalah kepala sekolah. Salah satu aspek dalam organisasi pendidikan yang paling berperan dalam peningkatan mutu pendidikan adalah kepala sekolah. Sebagaimana yang dikemukakan Supriadi bahwasanya ada hubungan yang erat antara kualitas kepala sekolah dengan berbagai aspek kehidupan sekolah seperti disiplin sekolah, iklim budaya sekolah, dan perilaku siswa. Dari sinilah tanggung jawab kepala sekolah dalam pengelolaan pendidikan mikro terkait dengan proses pembelajaran di sekolah. ${ }^{15} \mathrm{Hal}$ terpenting dalam menjadi kepala sekolah adalah harus mampu menunjukkan peran kepemimpinan yang baik.

Kepemimpinan formal merujuk kepada tugas kepala sekolah untuk memformulasikan visi dan misi serta tujuan organisasi sebagaimana peraturan perundang-undangan yang berlaku. Kepemimpinan administratif merujuk kepada tugasnya untuk melakukan pembinaan mengenai administrasi kepada seluruh staf dan seluruh anggota organisasi sekolah. Kepemimpinan supervisi merujuk kepada tugasnya untuk membantu dalam melakukan pembimbingan terhadap anggotanya supaya dapat menjalankan tugasnya dengan baik. Kepemimpinan organisasi merujuk kepada tugasnya untuk mengkondisikan dengan cara membuat iklim kerja yang kondusif, sehingga semua anggotanya dapat bekerja dengan produktif dan penuh antusias. Kepemimpinan tim merujuk kepada tugasnya untuk menciptakan kerjasama yang baik antar semua anggota agar tujuan organisasi sekolah dapat tercapai secara optimal. ${ }^{16}$

Dalam paradigma baru manajemen pendidikan, kepala sekolah yang profesional akan membawa dampak positif dan perubahan yang cukup mendasar dalam reformasi sistem pendidikan di sekolah. Dampak positif tersebut antara lain: 1) efektivitas proses pendidikan, 2) menumbuhkan kepemimpinan sekolah yang kuat, 3) efektivitas manajemen tenaga kependidikan meningkat, 4) budaya mutu,

\footnotetext{
${ }^{13}$ Iwan Purwanto, Manajemen Strategi, (Bandung: CV. Yrama Widya, 2012), hlm. 80-81.

${ }^{14}$ Agustinus Sri Wahyudi, Manajemen Strategik: Pengantar Proses Berfikir Strategik, (Bandung: Bina Rupa Aksara, 1996), hlm. 17.

${ }^{15}$ E Mulyasa, Menjadi Kepala Sekolah Profesional....., hlm. 25.

${ }^{16}$ Alben Ambarita, Kepemimpinan Kepala Sekolah....., hlm. 88.
} 
5) kerja sama tim yang kompak, cerdas, dan dinamis, 6) kemerdekaan, 7) komunitas sekolah dan partisipasi masyarakat, 8) manajemen yang transparan, 9) kemampuan berubah, 10) evaluasi dan peningkatan berkelanjutan, 11) menanggapi kebutuhan, 12) dapat dipertanggungjawabkan atau akuntabilitas tinggi, dan 13) keberlanjutan.

Keberhasilan kepala sekolah dapat dilihat dari kemampuannya dalam memahami organisasi sekolah yang merupakan organisasi yang kompleks, unik, dan khas. Selain itu, kepala sekolah yang berhasil harus mampu menjalankan peran dan fungsinya. Beberapa fungsi dari kepala sekolah, antara lain: 1) fungsi pendidik, 2) fungsi manajer, 3) fungsi administrator, 4) fungsi pengawas, 5) fungsi pemimpin, 6) fungsi inovator, dan 7) fungsi motivator. ${ }^{17}$

2. Mutu Pendidikan

\section{a. Pengertian Mutu}

Mutu atau kualitas dalam konteks pendidikan merujuk pada proses dan hasil pendidikan. Dari konteks "proses", pendidikan yang bermutu memerlukan berbagai masukan seperti bahan ajar: kognitif, afektif, dan psikomotorik,, metodologi yang beragam, yang cocok dengan kemampuan pengajar, masukan sekolah, suport administrasi, infrastruktur, sumber daya, serta menciptakan suasana yang kondusif dan lain-lain. Sedangkan dari konteks "hasil", pendidikan yang bermutu adalah pendidikan yang dapat menelorkan dan menciptakan lulusan yang memiliki kemampuan dasar (the principal skill) dalam belajar, sehingga dapat mengikuti bahkan menjadi pioner dalam pembaharuan dan perubahan dengan memberdayakan sumber daya pendidikan secara optimal melalui pembelajaran yang baik dan kondusif.

Pendidikan atau sekolah yang bermutu disebut juga sekolah yang unggul, sekolah favorit, sekolah efektif dan sekolah unggulan. Sekolah yang unggul dan berkualitas adalah sekolah yang mampu bersaing dengan siswa di dalam maupun di luar sekolah. Sekolah yang unggul dan berkualitas juga memiliki akar budaya dan nilai etika moral/akhlak yang santun dan kuat. ${ }^{18}$

b. Standar Mutu Pendidikan

Standar adalah ukuran yang dipakai untuk memberikan pengukuran dan penilaian terhadap sesuatu. Hal ini sangat urgen untuk diketahui, terutama dalam upaya merealisasikan pendidikan yang berkualitas. Jika merujuk kepada Peraturan Pemerintah (PP) Nomor 19 Tahun 2005 tentang Standar Nasional Pendidikan. Dalam standar nasional tersebut, terdapat 8 (delapan) unsur yang sangat penting untuk menjadi perhatian guna menghasilkan pendidikan yang berkualitas, antara lain: (1) standar isi; (2) standar proses; (3) standar kompetensi lulusan; (4) standar pendidik dan tenaga kependidikan; (5) standar sarana dan prasarana; (6) standar manajemen; (7) standar manajemen, dan (8) standar penilaian.

c. Upaya sekolah dalam meningkatkan mutu pendidikan

Ada beberapa hal yang dapat dilakukan oleh sekoalh dalam upayanya meningkatkan mutu pendidikan, antara lain sebagai berikut.

\footnotetext{
${ }^{17}$ Wahjosumidjo, Kepemimpinan Kepala Sekolah, Tinjauan Teoritis dan Permasalahannya, (Jakarta: Rajawali Press, 1999), hlm. 81.

${ }^{18}$ Abdul Chafidz, Sekolah Unggul Konsepsi dan Problematikanya, MPA No. 142, Juli, 1998, hlm. 39.
} 
(1) meningkatkan kualitas guru dengan mengikuti kursus pelatihan, kursus pendidikan, memperbanyak membaca, studi banding, dan menjalin hubungan dengan orang tua,

(2) meningkatkan kualitas bahan ajar,

(3) meningkatkan kualitas metode pengajaran,

(4) meningkatkan infrastruktur, serta

(5) meningkatkan kualitas pembelajaran.

3. Faktor-Faktor yang Mempengaruhi Peningkatan Mutu Pendidikan Ada dua faktor yang dapat mempengaruhi mutu atau kualitas pendidikan, yaitu faktor internal dan faktor eksternal. Faktor internal meliputi sumber daya manusia, siswa, finansial, kurikulum, organisasi, lingkungan fisik, perkembangan ilmu pengetahuan dan teknologi, peraturan, keikutsertaan masyarakat, dan kebijakan pendidikan. Sedangkan faktor eksternal meliputi kekurang-aktifan dalam bidang politik, ekonomi yang tidak condong kepada bidang pendidikan, sosial budaya, dan kurangnya dalam memanfaatkan ilmu pengetahuan dan teknologi. ${ }^{19}$

Hubungannya dengan upaya meningkatkan kualitas dan mutu pendidikan di suatu lembaga pendidikan, bisa memakai dan menerapkan model Manajemen Peningkatan Mutu Berbasis Sekolah (MPMBS) yang memfokuskan kepada sekolah sebagai kekuatan utama (main power) dalam upaya meningkatkan mutu dan kualitas. Pendekatan yang dapat diaplikasikan dalam hal ini adalah pendekatan input-prosesoutput. Terdapat berbagai kriteria dan karakteristik sekolah yang wajib diwujudkan, adalah sebagai berikut:

a. Input pendidikan, meliputi:

(1) kebijakan mutu,

(2) sumber daya tersedia dan siap,

(3) memiliki harapan prestasi tinggi, serta

(4) fokus pada pelanggan khususnya peserta didik.

b. Input Manajemen

Kepala sekolah dalam mengelola lembaganya memakai beberapa input pengelolaan. Masukan pengelolaan yang dimaksudkan di sini adalah kejelasan mengenai tugas, Menyusun perencanaan yang sistematis dan rinci, program yang sesuai dengan menyokong atas terlaksananya rencana, menyusun kejelasan peran dan aturan main sebagai tauladan bagi seluruh civitas akademika sekolah untuk berperilaku, dan tersedianya sistem yang baik dalam mengendalikan mutu dan kualitas yang tepat sasaran demi memastikan supaya target yang sesuai dengan kesepakatan bisa terealisasi. ${ }^{20}$

c. Proses Pendidikan, meliputi:

(1) Proses belajar mengajar efektif

(2) Leadership yang kuat.

(3) Manajemen tenaga kependidikan yang efektif.

(4) Budaya mutu dimiliki sekolah.

(5) Kekompakan dan kecerdasan dalam teamwork dimiliki sekolah

(6) Kemandirian dan kewenangan dimiliki sekolah

\footnotetext{
${ }^{19}$ Syafarudin, Manajemen Mutu Terpadu dalam Pendidikan, (Jakarta: Grasindo, 2002), hlm. 14.

${ }^{20}$ Depdiknas, Manajemen Peningkatan Mutu....., hlm. 19.
} 
Leadership: Jurnal mahasiswa manajemen pendidikan Islam

ISSN (P): 2721-7108, ISSN (E): 2715-0399

Vol. 03 No. 01 bulan Desember 2021

(7) Keikutsertaan masyarakat dan warga sekolah

(8) Transparansi pengelolaan dimiliki Sekolah

(9) Kebersediaan sekolah untuk siap berubah

(10) Senantiasa menjalankan evaluasi dan juga memperbaiki kelemahan secara berkesinambungan.

(11) Senantiasa cepat tanggap dan bersifat preventif terhadap kebutuhan

(12) Akuntabilitas dimiliki sekolah

d. Output Pendidikan

Ouput adalah performen sekolah. Performen sekolah berarti capaian-capaian yang didapatkan dari setiap langkah yang dilakukan sekolah. Performen sekolah dinilai dari mutu, efektifitas, inovasi, efisiensi, moral kerja, dan kualitas produktifitas. $^{21}$

Beberapa faktor yang dapat menentukan performen sekolah, yaitu:

a. Fleksibiltas kurikulum

b. Efektivitas aktifitas belajar mengajar

c. Sumber daya yang melingkupi sekolah, baik lingkungan sekolah, SDM dan sumber daya lain.

C. Hasil dan Pembahasan

d. Standarisasi pengajar. ${ }^{22}$

Strategi Kepala Sekolah dalam Meningkatkan Mutu Pendidikan di Madrasah Aliyah Bahrul Ulum Tajinan Kabupaten Malang

a. Meningkatkan Kualitas Tenaga Pendidikan dan Kependidikan

Salah satu cara meningkatan SDM yang diaplikasikan oleh kepala sekolah ialah melalui pengiriman tenaga pendidik juga tenaga kependidikan ke dalam workshop berdasar kepada kemampuan dan kompetensinya. Yang menjadi goal dari aktifitas ini adalah supaya kompetensi profesional tenaga pendidik dan kependidikan mengalami peningkatan. Selain dilibatkan aktif dalam workshop, tenaga pendidik dan kependidikan juga diikut sertakan dalam kegiatan penataran, seminar, diklat, kompetensi.

b. Pembinaan Kedisiplinan Guru dan Siswa

Di Madrasah Aliyah Bahrul Ulum Tajinan, upaya pembinaan kepala sekolah dalam meningkatkan kedisiplinan guru dan murid yaitu dengan cara membuat peraturan untuk guru datang lebih awal dari kedatangan siswa. Guru yang ada jadwal hari itu, wajib datang terlebih dahulu untuk menyambut kedatangan siswa. Guru yang terlambat datang akan dipanggil ke ruang kepala sekolah untuk di kasih teguran. Adapun siswa yang terlambat datang maka akan dikenai denda sebesar Rp. 2.000. hal ini bertujuan untuk memberi efek jera pada siswa yang terlambat.

(c) Meningkatkan Efektivitas Pembelajaran

Bapak Noer Azizi selaku kepala madrasah, beliau berpendapat bahwa salah satu yang ikut berperan dalam meningkatkan mutu pendidikan yaitu peserta didik. Maka dari itu, bagaimana caranya peserta didik memperoleh pembelajaran dengan situasi yang efektif dan efisien, yaitu dengan materi dan metode yang disampaikan harus sesuai. Bagaimana caranya mendapatkan metode dan materi

${ }^{21}$ Ibid...., hlm. 11 .

${ }^{22}$ Nanang Fattah, Konsep Manajemen Berbasis Sekolah (MBS) dan Dewan Sekolah, (Bandung: Pustaka Bani Quraisy, 2004), hlm. 71-72. 
yang sesuai, yaitu dengan adanya guru yang profesional dan kompeten di bidangnya. Oleh karena itu bapak Noer Azizi selalu memberikan perhatian khusus dalam proses perekrutan tenaga pendidik atau guru. Semakin kompeten dan profesional seorang guru di bidangnya, maka akan semakin baik pula metode dan meteri yang akan di sampaikan kepada peserta didik, sehingga peserta didik akan memperoleh pembelajaran yang efektif dan efisien.

(d) Meningkatkan Sarana dan Prasarana Madrasah

Dari hasil pengamatan peneliti di Madrasah Aliyah Bahrul Ulum Tajinan mengenai sarana dan prasarannya, Menurut Bapak Noer Azizi, bahwa upaya dalam meningkatkan infrastruktur sangatlah penting, dikarenakan infrastruktur tersebut menjadi penunjang proses pembelajaran serta mampu menjadi daya tarik masyarakat. Oleh karena itu beliau terus meningkatkan sarana dan prasarananya dengan melakukan pembenahan dan pembuatan gedung baru yang nantinya akan difungsikan sebagai musholla, dan ruang perpustakaan. Karena kedua ruang tersebut masih belum punya, dan selama ini masih bergabung dengan MTs Bahrul Ulum.

(e) Meningkatkan Kualitas Belajar dan Prestasi Siswa

Dalam setiap proses belajar mengajar yang dialami peserta didik tidak selamanya lancar seperti yang diharapkan, terkadang mengalami kesulitan atau hambatan dalam belajar. Kendala tersebut perlu diatasi dengan berbagai usaha, yakni dengan senantiasa memberikan rangsangan dan memberikan motivasi belajar.

(f) Evaluasi Proses Belajar Mengajar kepala sekolah di Madrasah Aliyah Bahrul Uum Tajinan. Bapak Noer Azizi selalu melakukan evaluasi terhadap guru terkait dengan kekurangan guru ketika mengajar. Hal tersebut dilakukan dengan cara memanggil guru yang bersangkutan, kemudia diberikan pengarahan agar menjadi lebih baik lagi kedepannya. Selain itu, rapat bulanan selalu dijalankan dengan rutin, diluar jam belajar, ketika kegiatan belajar mengajar telah selesai. Hal ini untuk mengevaluasi bagaimana kesiapan guru dalam mengajar. Mulai dari membahas RPP, silabus, dan lain-lain yang bersangkutan dengan proses belajar mengajar, sehingga efektivitas dan efisiensi proses belajar mengajar dapat tercapai.

(g) Mempromosikan Madrasah

Promosi ialah salah satu cara untuk menyaring dan mendapatkan murid baru di Madrasah Aliyah Bahrul Ulum Tajinan. Kegiatan ini memiliki goal agar masyarakat mengetahui wujud adanya madrasah ini serta mengetahui capaian-capaian yang pernah diraih oleh Madrasah Aliyah Bahrul Ulum, sehingga masyarakat lebih memilih untuk memasukkan anak-anaknya di Madrasah Aliyah Bahrul Ulum Tajinan.

\section{Kesimpulan dan Saran}

Mengacu kepada pembahasan di atas, maka penelitian ini dapat disimpulkan sebagai berikut: bahwa strategi kepala sekolah dalam meningkatkan mutu pendidikan Madrasah Aliyah Bahrul Ulum Tajinan adalah dengan senantiasa pawai membaca kondisi madrasah, memanfaatkan semaksimal mungkin potensi-potensi yang ada di madrasah, baik tenaga pendidik dan kependidikan, peserta didik, dan sarana prasarana madarsah.

Adapun saran yang diberikan peneliti adalah untuk kepala sekolah agar selalu memperhatikan mutu pendidikan dari input, proses hingga outputnya. Sedangkan bagi 
Leadership: Jurnal mahasiswa manajemen pendidikan Islam

ISSN (P): 2721-7108, ISSN (E): 2715-0399

Vol. 03 No. 01 bulan Desember 2021

guru agar selalu meningkatkan kedisiplinan mengajar maupun administrasi, dan bagi siswa hendaknya selalu meningkatkan kedisiplinan belajar akademik maupun non akademik.

\section{DAFTAR PUSTAKA}

Ahmad Sonhaji, 2003. Metode Penelitian Kualitatif Dalam Pendidikan. Banjarmasin: Universitas Lambung Mangkurat.

Agustinus Sri Wahyudi, 1996. Manajemen Strategik: Pengantar Proses Berfikir Strategik. Bandung: Bina Rupa Aksara.

Alben Ambarita, 2015. Kepemimpinan Kepala Sekolah. Yogyakarta: Graha Ilmu.

Aycan Z, Schyns B, Sun J-M, 2013. Convergence and Divergence of Paternalistic Leadership: a Cross Cultural Cultural Investigation of Prototypes. Journal of International

Bussiness Studies.

Abdul Chafidz, Juli 1998. Sekolah Unggul Konsepsi dan Problematikanya. MPA. NO. 142.

Ara Hidayat, Imam Machali, 2016. The Handbook of Education Management: Teori dan Praktik Pengelolaan Sekolah/Madrasah di Indonesia: Di lengkapi Dengan Undang- $\quad$ Undang No. 20 Tahun 2003, Tentang Sistem Pendidikan Nasional, PP No. 32 Tahun 2013 Tentang Perubahan atas PP No. 19 Tahun 2005 Tentang Standar Nasional Pendidikan. Kencana, Prenadamedia Group.

Ahmad Supriyanto, November 1997. Mutu Pendidikan Sekolah Dasar Di Daerah Diseminasi. IKIP. Jurnal IImu Pendidikan, Jilid 4.

Departemen Pendidikan Nasional, 2000. Manajemen Peningkatan Mutu Berbasis Sekolah. Jakarta.

David Fred R, 2006. Manajemen Strategi, Edisi Kesepuluh. Jakarta: Salemba Empat.

Endang Mulyasa, 2007. Menjadi Kepala Sekolah Profesional. Bandung: PT. Remaja Rosdakarya.

Fattah, Nanang, 2004. Konsep Manajemen Berbasis Sekolah (MBS) dan Dewan Sekolah. Bandung: Pustaka Bani Quraisy.

Farh JL. And Cheng BS, 2000. Acultural Analysis of Paternalistic Leadership in Chinese Organization. In:Li JT, Tsui AS and Weldon E (eds) Manajement and

Organization in the Chinese Context. London: Macmillan.

Hamdani, 2011. Strategi Belajar Mengajar. Bandung: CV. Pustaka Setia.

Iskandar Wassid, Dadang Sunendar. Strategi Pembelajaran Bahasa. Bandung: PT. Remaja Rosdakarya.

Jerome S. Arcaro, 2006. Pendidikan Berbasis Mutu. Jogjakarta: Pustaka Pelajar.

Jennifar L. Epley. July 2015. Weber's Theory of Charismatic Leadership: The Case of Muslim Leaders in Contemporary Indonesian Politics. International Journal of Humanities and Social Science, Vol. 5, No. 7.

Jim Allen Mc. Clesky, 2014. Situational, Tranformational, and Transactional Leadership and Leadership Development. Journal of Bussiness Studies Quarterly, Vol. 5, No. 4.

Lexy J. Meleong, 2010. Metodologi Penelitian Kualitatif. Bandung: Remaja Rosdakarya.

Roestiyah N.K. Masalah Ilmu Keguruan. Jakarta: Bina Aksara

Ramayulis dan Mulyadi, 2017. Manajemen dan Kepemimpinan Pendidikan Islam. Jakarta: Kalam Mulia. 
Leadership: Jurnal mahasiswa manajemen pendidikan Islam

ISSN (P): 2721-7108, ISSN (E): 2715-0399

Vol. 03 No. 01 bulan Desember 2021

Sanghan Choi, 2007. Democratic Leadership: The Lessons of Exemplary Models for Democratic Governance, International Journal of Leadership Studies, Vol. 2

S. Nasution, 1998. Metode Penelitian Natwalistik-Kualitatif. Baajaag: Talsito.

Trucker R.C, 1977. Personality and Political Leadership and Political Science Quarterly, 92 (3).

Terente Jackson, 2016. Peternalistic Leadership: The Missing Link in Cross Cultural Studies, International Journal of Cross Cultural Management, Vol. 16.

Wahjosumidjo, 1999. Kepemimpinan Kepala Sekolah, Tinjauan Teoritis dan Permasalahannya. Jakarta: Rajawali Press.

Zakeer A, 2016. Leadership Theories and Styles: A Literature Review. Journal of Recources Development and Management, Vol. 16. 